\title{
Distribution and composition of organic matter in sediments of the oxygen minimum zone of the Northeastern Mexican Pacific: paleoceanographic implications
}

\author{
Distribución y composición de la materia orgánica en sedimentos de la \\ zona de oxígeno mínimo del Pacífico nororiental mexicano: implicaciones \\ paleoceanográficas
}

\author{
A. Sánchez ${ }^{1 *}$, B. E. López-Ortiz ${ }^{1,2}$, S. Aguíñiga-García ${ }^{1}$, E. Balart ${ }^{3}$ \\ ${ }^{I}$ Centro Interdisciplinario de Ciencias Marinas - Instituto Politécnico Nacional, La Paz, Apdo. postal \# 592, La Paz, \\ Baja California Sur, México. \\ ${ }^{2}$ Instituto Politécnico Nacional, La Paz, Apdo. postal \# 592, La Paz, Baja California Sur, México. \\ ${ }^{3}$ Centro de Investigaciones Biológicas del Noroeste, La Paz, B.C.S., México. \\ *Corresponding author: alsanchezg@ipn.mx; alsanchezg13@gmail.com
}

Received: 29/04/2011 / Accepted: 12/04/2013

\begin{abstract}
Total organic carbon (TOC) content, total nitrogen $(\mathrm{TN})$ content, elemental $(\mathrm{C}$ and $\mathrm{N})$, and isotopic $\left(\delta^{13} \mathrm{C}-\mathrm{TOC}\right)$ composition of organic matter derived from both marine and terrestrial sources constrain the relative contributions from marine productivity, the mangroves, and the continental wind erosion of 36 carbonate-free surface sediments along the southwestern coast of the Baja California Peninsula. In general, the spatial patterns of TOC, TN, C:N ratio and $\delta^{13} \mathrm{C}-\mathrm{TOC}$ are similar. The maximum content of TOC $(14.5 \%)$ and $\mathrm{TN}(1.6 \%)$ were measured inside the oxygen minimum zone (OMZ). The stable carbon isotopic compositions were enriched in ${ }^{12} \mathrm{C}$ in surface sediments at suboxic sites within the OMZ. The C:N ratio and $\delta^{13} \mathrm{C}-\mathrm{TOC}$ values indicated that the organic sediment material is predominantly of marine origin, with a minor contribution from the terrestrial source or mangroves. In the stations near to the coast, the high values of the $\mathrm{C}: \mathrm{N}$ ratio and the depleted ${ }^{13} \mathrm{C}$ values suggest a proportionally greater accumulation of terrestrial organic matter. The terrestrial-derived organic carbon content is $<10 \%$ at the continental margin and $>40 \%$ at the stations near to the coast, based on a Mixing Model of End Members.
\end{abstract}

Keywords: Total organic carbon, total nitrogen, carbon stable isotopes, oxygen minimum zone, northeastern Pacific

\section{Resumen}

El contenido de carbono orgánico total (COT), nitrógeno total (NT), la composición elemental ( $\mathrm{C}$ y $\mathrm{N})$ e isotópica derivada de fuentes marina y terrestre ha permitido delimitar la contribución relativa de la productividad marina, los manglares y la erosión continental (é́licos) de 36 muestras de sedimentos superficiales (libres de carbono inorgánico) en el margen SW de Baja California. En general, la distribución espacial de COT, NT, la razón C:N y el $\delta^{13} \mathrm{C}-\mathrm{COT}$ son similares. El contenido máximo de COT (14.5\%) y NT (1.6\%) fue observado dentro de la zona de oxígeno mínimo. La composición isotópica de carbono está enriquecida en ${ }^{12} \mathrm{C}$ en sedimentos superficiales de sitios subóxicos dentro de la ZOM. La razón C:N y los valores del $\delta^{13} \mathrm{C}$-COT indicaron que el material 
orgánico en sedimentos es predominantemente de origen marino con una menor contribución terrestre o de manglar. En las estaciones cercanas a la costa, los mayores valores de la razón C: $\mathrm{N}$ y los valores empobrecidos en ${ }^{13} \mathrm{C}$ sugieren una acumulación mayor de materia orgánica terrestre. El contenido de carbono orgánico derivado de origen terrestre es $<10 \%$ en el margen continental y $>40 \%$ en estaciones cercanas a la costa sobre la base del modelo de mezcla de "end-members".

Palabras clave: Carbono orgánico total, nitrógeno total, isótopos estables de carbono, zona de oxígeno mínimo, Pacíico nororiental

\section{Introduction}

The burial of organic matter $(\mathrm{OM})$ in the continental margin is an important process in the global carbon cycle, because more than $90 \%$ of the carbon buried in the oceans is located in this area (e.g., Berner, 1982; Walsh, 1991). Only $2.5 \%$ to $4 \%$ of the biologically fixed carbon is actually buried in the sediments, whereas the great majority is remineralized (Muller-Karger et al., 2005). The OM in continental margin sediments can be supplied both from autochthonous sources (such as phytoplankton) and allochthonous sources (such as terrestrial; Hedges et al., 1997). Bulk organic $\delta^{13} \mathrm{C}$ and $\mathrm{C}: \mathrm{N}$ ratio have been widely used to elucidate the source and fate of organic matter in the terrestrial, estuarine, coastal regions and continental margin (e.g., $\mathrm{Hu}$ et al., 2006; Cowie et al., 2009; Walinsky et al., 2009; Baumgart et al., 2010). However, most studies of the origin and composition of OM have been focused on estuary systems and only a few studies (e.g., Sánchez and Carriquiry, 2007a,b; Aguíñiga et al., 2010; Sánchez et al., 2010) have been made in arid systems where the transport by river or arroyos is null, the aeolian transport is the main source of terrigenous material and the coastal upwelling is responsible for marine productivity in continental margin.

In Bahia Todos Santos, Baja California, sediments in deep-water (depth $<200 \mathrm{~m}$ ) are fine grained (Sánchez et al., 2009, 2011), rich in organic carbon (OC), and have generally low $\delta^{13} \mathrm{C}$ values. The sediments in highenergy environments are poor in $\mathrm{OC}$ and have high $\delta^{13} \mathrm{C}$ values. A bivariate isotopic mixing model indicates that none of the sediments samples contain $>50 \%$ terrigenous OC (average $\sim 30 \%$ ), and that the terrigenous OC content of the sediments is a small proportion of the OC content of local soils. Sediment OC composition is apparently controlled by energy-related sorting and deposition, oxidation of much of the original terrigenous OC, and replacement of some terrigenous OC by marine OC (Smith et al., 2008).

The rates of accumulation of organic carbon, nitrogen and phosphorus $\left(\mathrm{C}_{\text {org }}, \mathrm{N}_{\text {org }}, \mathrm{P}_{\text {org }}\right)$, and of biogenic silica (BSi) were measured in sediment cores (GC31 and PC08) collected within the oxygen minimum zone of the Magdalena margin, off western Baja California Sur (Mexico; Sánchez and Carriquiry, 2007a,b). The C:N ratio throughout the sedimentary register in the sediment cores GC31 and PC08 was $\sim 10$ on average, with a maximum of $\sim 13$ and minimum of 8 . Thus, the main source of organic matter to the Magdalena margin has been predominantly of marine origin. The BSi fluxes along the Magdalena margin indicated that diatoms were the predominant source of organic matter (Sánchez and Carriquiry, 2007a,b).

Most surface sediments of south-western Mexican coast (between $15.95^{\circ} \mathrm{N}$ and $23.11^{\circ} \mathrm{N}$; water depths from 24 to $1400 \mathrm{~m}$ ) have relatively low $\mathrm{C}: \mathrm{N}$ ratios ( $\sim 6$ to $10)$, suggesting dominant fluxes of algae. Samples with higher ratios ( $\sim 12$ to 15.4$)$ reflect fluxes with more landplant derived organic material. In this area, $\delta^{13} \mathrm{C}-\mathrm{OC}$ varies from $-25.91 \%$ o to $-21.35 \%$. While values ranging between $-22 \%$ and $-21 \%$ suggest sediment dominated by marine organic matter, more negative $\delta^{13} \mathrm{C}-\mathrm{OC}$ values may be interpreted as marine material mixed with a greater proportion of land-derived organic matter consisting of C3 plants (Limoges et al., 2010).

In the Gulf of Mexico, the $\mathrm{C}: \mathrm{N}$ ratio suggests that the organic matter in the superficial sediments has a mixed hemipelagic-terrigenous origin, that depends on the distance from the coast. This is a major contrast to opencoast gradients where $\mathrm{C}: \mathrm{N}$ values remain constant, and thus this ratio is characteristic of a marginal sea, showing alternating periods of high terrigenous and photoautotrophic input (Escobar-Briones and García-Villalobos, 2010).

The SW Baja California Peninsula margin is characterized by coastal upwelling, the presence of an intense oxygen minimum zone and the Bahia Magdalena-Almejas lagoon complex that contains $90 \%$ of mangroves in Baja California Sur. The objective of this work is to provide information on the sources and origin of organic matter in continental margin sediments along the southwestern Baja California Peninsula. The observed distributional pattern for organic matter content and its composition in these modern sediments provide a baseline to guide future paleo-environmental research for the short (ENSO, PDO index) to long (Holocene or Ice Age) term. 


\section{Methods}

The sediment samples were collected in November 2006 by using a Smith-McIntyre grab along nine transects perpendicular to the coastline, to form a spatial arrangement of 37 stations in the range of 70- to 500 -m depth (Fig. 1). The top $2 \mathrm{~cm}$ of the samples were preserved by freezing. Prior to geochemical analyses, only 37 samples of sediments were dried, crushed with an agate mortar and homogenized. Samples were treated in the laboratory with hydrochloric acid to decalcify samples and remove the inorganic carbon before the elemental analysis of total organic carbon (TOC) and nitrogen (TN), and the stable carbon isotopes. The samples were dried in an oven at $50^{\circ} \mathrm{C}$ and encapsulated for elemental and isotopic analysis. The TOC and TN compositions were determined on 5 to $6 \mathrm{mg}$ of each sediment sample by high temperature combustion using a COSTECH 4010 elemental analyzer. Replicated measurements of Urea and BBOT (2,5-Bis(5-tert-butyl- 2-benzoxazolyl) thiophene) showed a relative deviation of $\pm 0.05 \%$ for the TOC and $\pm 0.05 \%$ for TN. Sediment samples for carbon isotopic analysis of organic matter were acidified with $1 \mathrm{~N} \mathrm{HCl}$, crushed and homogenized. Stable isotope data were obtained using a COSTECH 4010 elemental analyzer coupled to a Finigan Delta Plus $\mathrm{V}$ mass spectrometer in the CICIMAR-IPN. The limit detection of mass spectrometer is 0.006 for $\mathrm{CO}_{2}$ and 0.01 for $\mathrm{N}_{2}$. Values were reported in $\delta$-notation (\%) according to the international Vienna-Pee Dee belemnite (V-PDB) reference:

$$
\delta^{13} \mathrm{C}(\%)=\left(\left({ }^{13} \mathrm{C} /{ }^{12} \mathrm{C}_{\text {sample }}{ }^{13} \mathrm{C} /{ }^{12} \mathrm{C}_{\text {reference }}\right)-1\right) \times 1000
$$

The $\delta^{13} \mathrm{C}$ values were calibrated using two standards BBOT and Urea and yielded a relative deviation of $\pm 0.2 \%$ o $v$. V-PDB.

We attempted to assess the relative proportions of terrestrial and marine organic matter present in sediments of the study area. The approach is based on the mixing model of Schultz and Calder (1976), which assumes $\delta^{13} \mathrm{C}$

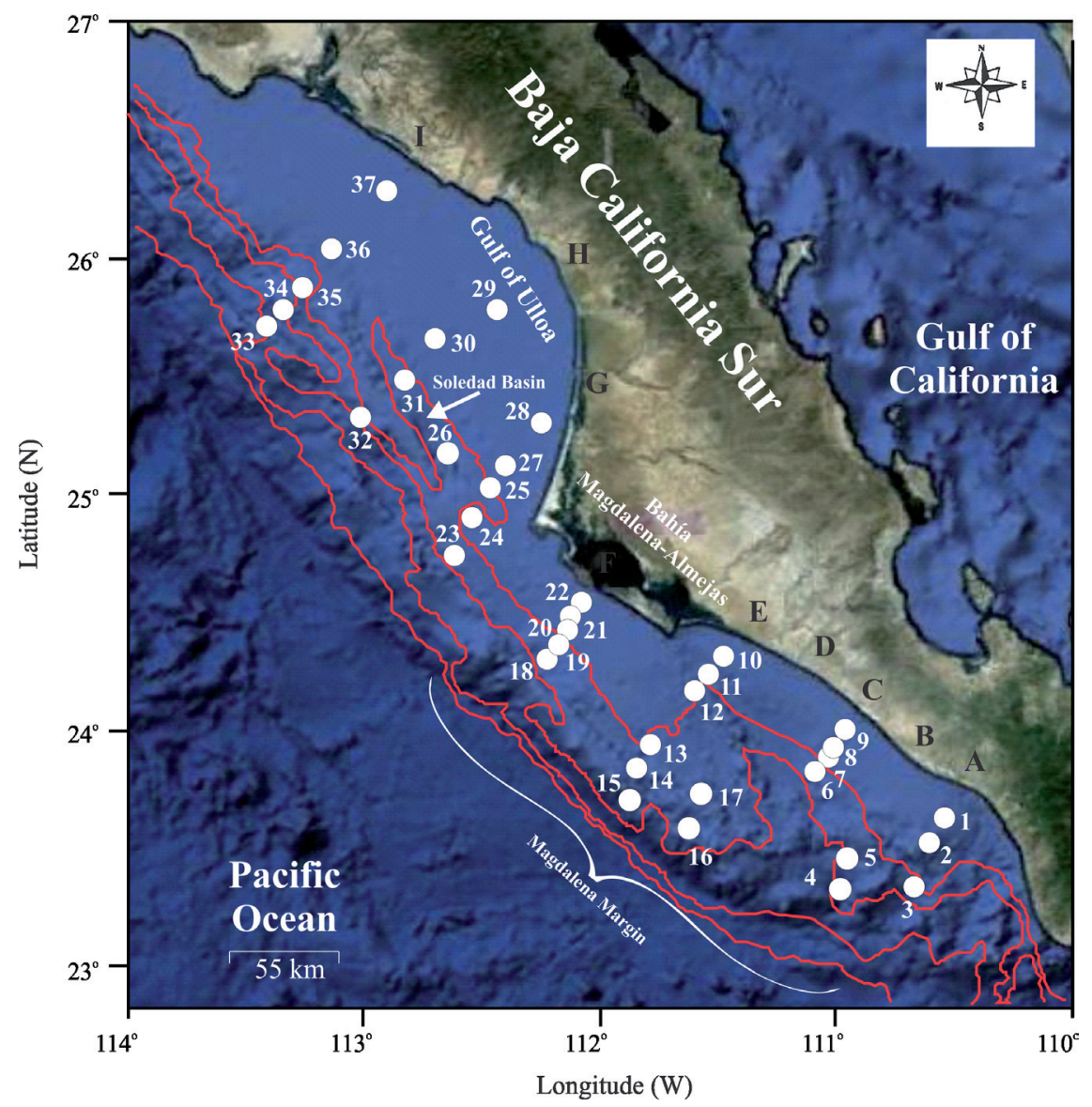

Fig. 1.- Stations of the surface sediments along the coast of the southwestern Baja California Peninsula, Mexico. The letters A to I denote the sampling transects perpendicular to the coastline. The continuous red lines are the isolines of bathymetry (200-, 500-, 1000-, and 2000-m depth).

Fig. 1.- Estaciones de sedimentos superficiales a lo largo de la costa suroccidental de la Península de Baja California, México. Las letras A a I denotan los transectos de muestreo perpendiculares a la línea de costa. Las líneas rojas continuas son las isolíneas de batimetría (200-, 500-, 1000-, y $2000 \mathrm{~m}$ de profundidad). 

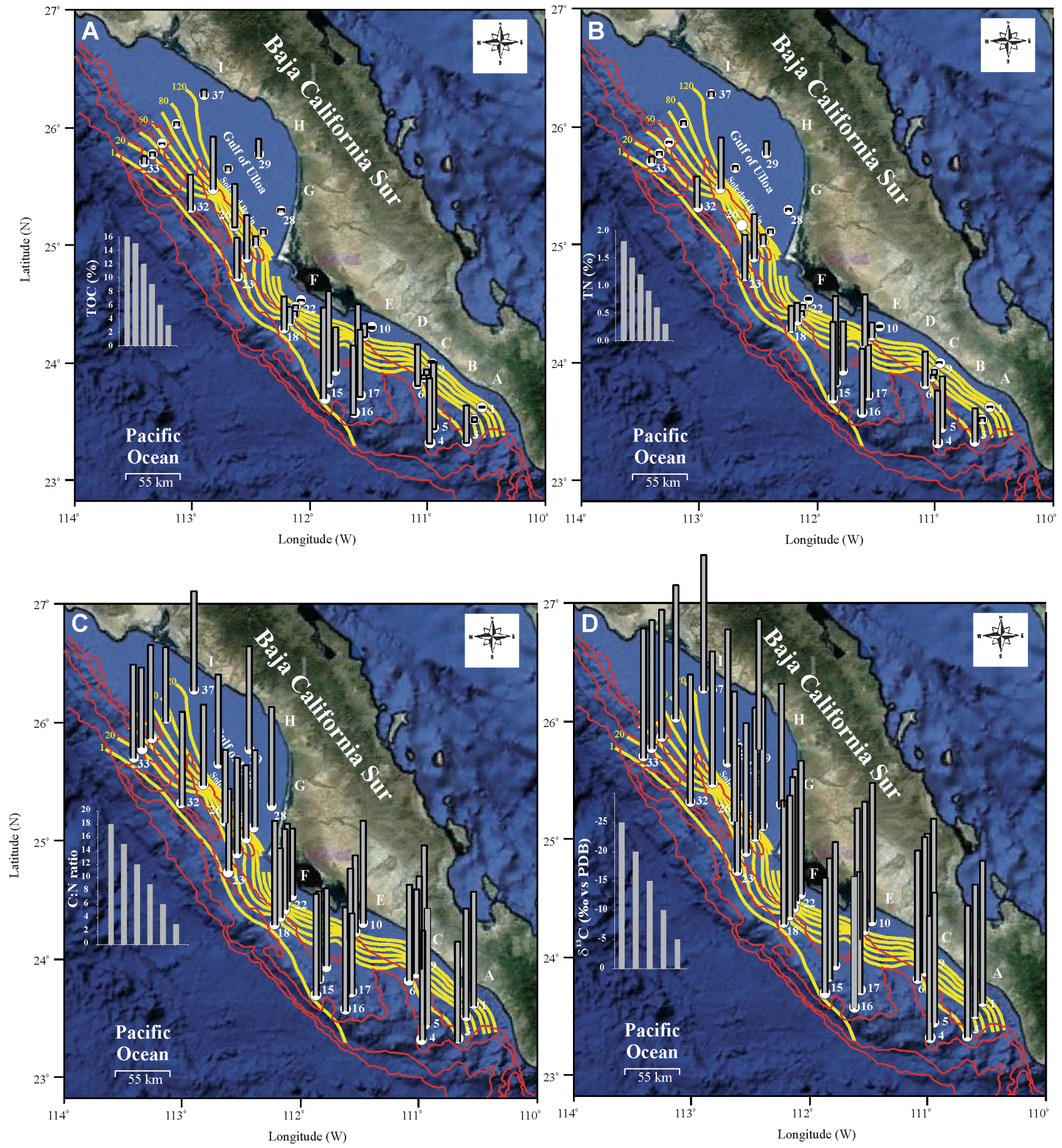

Fig. 2.- Spatial distribution of several parameters along the southwestern Baja California Peninsula, Mexico. The letters A to I denote the sampling transects perpendicular to the coastline. The red lines are the bathymetric contours (200-500-, 1000-, and 2000-m depth), the continuous black lines are the concentration of dissolved oxygen $\left(\mu \mathrm{mol} \mathrm{kg}^{-1}\right)$ with the change of depth. A. total organic carbon (TOC, \%), B. total nitrogen (TN, \%); C. C:N ratio (molar); D. $\delta^{13} \mathrm{C}-\mathrm{TOC}$ (\%o vs. PeeDee Belemnite, PDB).

Fig. 2.- Distribución espacial de varios parámetros a lo largo de la costa suroccidental de la Península de Baja California, México. Las letras A a I denotan los transectos de muestreo perpendiculares a la línea de costa. Las líneas rojas continuas son las isolíneas de batimetría (200-, 500-, 1000-, y $2000 \mathrm{~m}$ de profundidad). La línea negra continua representa la concentración de oxígeno disuelto $\left(\mu \mathrm{mol} \mathrm{kg}^{-1}\right)$ con el cambio de la profundidad. A. carbono orgánico total (COT, \%); B. nitrógeno total (NT, \%); C. razón C:N (molar); D. $\delta^{13} \mathrm{C}-\mathrm{COT}$. 


\begin{tabular}{cccccccc} 
Station & $\begin{array}{c}\text { Depth } \\
(\mathrm{m})\end{array}$ & $\begin{array}{c}\text { DO } \\
(\mu \mathrm{mol} / \mathrm{kg})\end{array}$ & $\begin{array}{c}\text { TOC } \\
(\%)\end{array}$ & $\begin{array}{c}\text { TN } \\
(\%)\end{array}$ & $\begin{array}{c}\text { C:N } \\
\text { ratio }\end{array}$ & $\begin{array}{c}\delta^{13} \mathrm{C} \\
(\%)\end{array}$ & Zone \\
\hline 1 & 69 & 49 & 0.18 & 0.02 & 11.9 & -24.1 & Coastal \\
2 & 95 & 27 & 0.67 & 0.06 & 11.3 & -22.3 & $\mathrm{CM}$ \\
3 & 158 & 11 & 5.53 & 0.61 & 10.4 & -22.3 & $\mathrm{CM}$ \\
4 & 474 & 11 & 9.90 & 0.95 & 12.1 & -20.9 & $\mathrm{CM}$ \\
5 & 570 & 32 & 9.60 & 0.98 & 11.4 & -22.0 & $\mathrm{CM}$ \\
6 & 278 & 6 & 6.81 & 0.69 & 11.4 & -22.0 & $\mathrm{CM}$ \\
7 & 190 & 13 & 0.64 & 0.07 & 10.0 & -23.0 & $\mathrm{CM}$ \\
8 & 112 & 34 & 0.95 & 0.10 & 11.1 & -22.7 & $\mathrm{CM}$ \\
9 & 69 & 90 & 0.30 & 0.02 & 13.5 & -23.6 & Coastal \\
10 & 38 & 205 & 0.31 & 0.03 & 12.2 & -23.6 & Coastal \\
11 & 79 & 181 & 2.12 & 0.26 & 9.2 & -21.9 & $\mathrm{CM}$ \\
12 & 251 & 6 & 6.84 & 0.86 & 9.2 & -22.2 & $\mathrm{CM}$ \\
13 & 217 & 21 & 6.56 & 0.90 & 8.5 & -20.9 & $\mathrm{CM}$ \\
14 & 358 & 2 & 14.47 & 1.56 & 10.7 & -20.5 & $\mathrm{CM}$ \\
15 & 520 & 1 & 14.29 & 1.37 & 12.1 & -19.5 & $\mathrm{CM}$ \\
16 & 550 & 2 & 11.00 & 1.33 & 9.6 & -20.5 & $\mathrm{CM}$ \\
17 & 430 & 1 & 11.37 & 1.07 & 12.3 & -22.3 & $\mathrm{CM}$ \\
18 & 344 & 5 & 5.25 & 0.49 & 12.4 & -20.9 & $\mathrm{CM}$ \\
19 & 227 & 12 & 2.57 & 0.36 & 8.3 & -20.5 & $\mathrm{CM}$ \\
20 & 172 & 22 & 0.82 & 0.09 & 9.6 & -22.3 & $\mathrm{CM}$ \\
21 & 113 & 56 & 0.55 & 0.06 & 9.3 & -22.2 & $\mathrm{CM}$ \\
22 & 70 & 161 & 0.24 & 0.03 & 7.9 & -22.6 & Coastal \\
23 & 379 & 3 & 0.45 & 0.04 & 9.7 & -21.4 & $\mathrm{CM}$ \\
24 & 138 & 8 & 0.77 & 0.07 & 11.4 & -21.9 & $\mathrm{CM}$ \\
25 & 333 & 3 & 1.42 & 0.19 & 8.7 & -22.0 & $\mathrm{CM}$ \\
26 & 501 & 3 & 7.47 & 0.75 & 11.3 & -22.3 & $\mathrm{CM}$ \\
27 & 93 & 94 & 6.84 & 0.87 & 9.1 & -22.4 & $\mathrm{CM}$ \\
28 & 45 & 268 & 6.29 & 0.87 & 11.7 & -20.9 & Coastal \\
29 & 45 & 268 & 2.80 & 0.26 & 12.3 & -22.1 & Coastal \\
30 & 70 & 164 & 0.72 & 0.07 & 11.1 & -22.6 & $\mathrm{CM}$ \\
31 & 153 & 2 & 8.24 & 0.99 & 9.6 & -22.5 & $\mathrm{CM}$ \\
32 & 385 & 4 & 5.56 & 0.60 & 10.7 & -21.8 & $\mathrm{CM}$ \\
33 & 390 & 4 & 1.17 & 0.11 & 11.2 & -21.9 & $\mathrm{CM}$ \\
34 & 309 & 3 & 0.64 & 0.06 & 9.5 & -21.8 & $\mathrm{CM}$ \\
35 & 130 & 81 & 0.21 & 0.02 & 8.8 & -21.8 & $\mathrm{CM}$ \\
36 & 60 & 134 & 0.60 & 0.07 & 11.9 & -22.6 & $\mathrm{CM}$ \\
37 & 45 & 268 & 1.10 & 0.10 & 11.2 & -23.0 & Coastal \\
\hline & 5 & & &
\end{tabular}

Table 1.- Dissolved oxygen (DO $\mu \mathrm{mol} / \mathrm{kg}$ ). Total organic carbon (TOC) and total nitrogen (TN) weight percentages and $\mathrm{C}: \mathrm{N}$ ratio and stable isotopic carbon compositions $\left(\delta^{13} \mathrm{C}\right)$ in sediments from the southwestern coast of the Baja California Peninsula.

Tabla 1.- Oxígeno disuelto ( $\mathrm{DO} \mu \mathrm{mol} / \mathrm{kg}$ ). Porcentaje en peso de carbono orgánico total y nitrógeno total y la razón $\mathrm{C}: \mathrm{N}$ y la composición isotópica estable de carbono $\left(\delta^{13} \mathrm{C}\right)$ en sedimentos de la costa suroccidental de la Península de Baja California.

values of terrestrial and marine end-members. For the study area, we have chosen $-27 \%$ for the $\delta^{13} \mathrm{C}$ value of the terrestrial end-member. Likewise, we have assumed a value of $\delta^{13} \mathrm{C}$ of $-20.5 \%$ for the marine end-member for these calculations. Adopting the above end-member values, the relative percent of land-derived organic matter (\%) in individual sediment of the study area was estimated from the following equation (Schultz and Calder, 1976; Minoura et al., 1997):

$$
\begin{gathered}
\text { \% Terrestrial Organic Matter }= \\
=\left[\left(\delta^{13} \mathrm{C}_{\text {marine }}-\delta^{13} \mathrm{C}_{\text {organic }}\right) /\left(\delta^{13} \mathrm{C}_{\text {marine }}-\delta^{13} \mathrm{C}_{\text {terrestrial }}\right)\right] \times 100
\end{gathered}
$$

The data were processed in DODESSYS software for the identification and separation of discordant outliers under the single-outlier type tests (Verma and DíazGonzález, 2012). For the evaluation of one observation at a time, these tests are based on the new precise and accurate critical values simulated by Verma et al. (2008). Statistical parameters (mean and standard deviation) were provided by this software after ascertaining that the data were free from discordant outliers.

\section{Results}

The analytical results as well as statistical parameters are summarized in Table 1. For the totality of data, DODESSYS software indicated that all observations were probably drawn from a normal distribution and only one discordant observation was obtained for $\mathrm{C} / \mathrm{N}$ ratio.

\subsection{Spatial distribution of TOC and TN}

The TOC and TN spatial distribution are shown in Figures $2 \mathrm{a}$ and $2 \mathrm{~b}$, respectively. The distribution of TOC and TN shows two trends: (1) TOC and TN contents increase in an offshore direction for transects A, B, C, D, E, F, G, and H; and (2) the content of TOC was high in Soledad Basin (transect $\mathrm{H}$ ). The TOC decreases in a northwest direction toward transect I. The contents of TOC are $>7 \%$ at stations deeper than $200 \mathrm{~m}$ in transects A, B, C, D, E, F, G, and H (Fig. 2a; Table 1). Two regions with a high content of TOC were identified in the study area; a large area located on the Magdalena margin and in the Soledad Basin in the northwest margin. Both regions are characterized by low concentrations of dissolved oxygen in the water column $(<20 \mu \mathrm{mol} \mathrm{kg}$ 1; Table 1). The coastal stations showed a low content of TOC ( $<3 \%$; Table 1) and high concentrations of dissolved oxygen $\left(>70 \mu \mathrm{mol} \mathrm{kg} \mathrm{kg}^{-1}\right.$; Table 1$)$.

\subsection{Spatial distribution of the $C: N$ ratio and $\delta^{13} C-T O C$}

The spatial distribution of the $\mathrm{C} / \mathrm{N}$ ratio and $\delta^{13} \mathrm{C}$-TOC is shown in Figures $2 \mathrm{c}$ and $2 \mathrm{~d}$, respectively. The $\mathrm{C}: \mathrm{N}$ ratio decreases in an offshore direction in transects $A, G$, $\mathrm{H}$, and $\mathrm{I}$, with the exception of transects $\mathrm{E}$ and $\mathrm{F}$ where it increases offshore. The $\mathrm{C}: \mathrm{N}$ ratio is homogeneous for transects B, C, and D. In general, shallower and coastal stations have a $\mathrm{C}: \mathrm{N}$ ratio $>12.2$ with the exception of station 22 with a $\mathrm{C}: \mathrm{N}$ ratio $<8.6$ (Fig. 2c; Table 1).Along the margin of the southwestern Baja California Peninsula, the stable isotopic composition of the TOC deposited along this arid location was more ${ }^{13} \mathrm{C}$-depleted in the offshore direction for all transects, with exception 


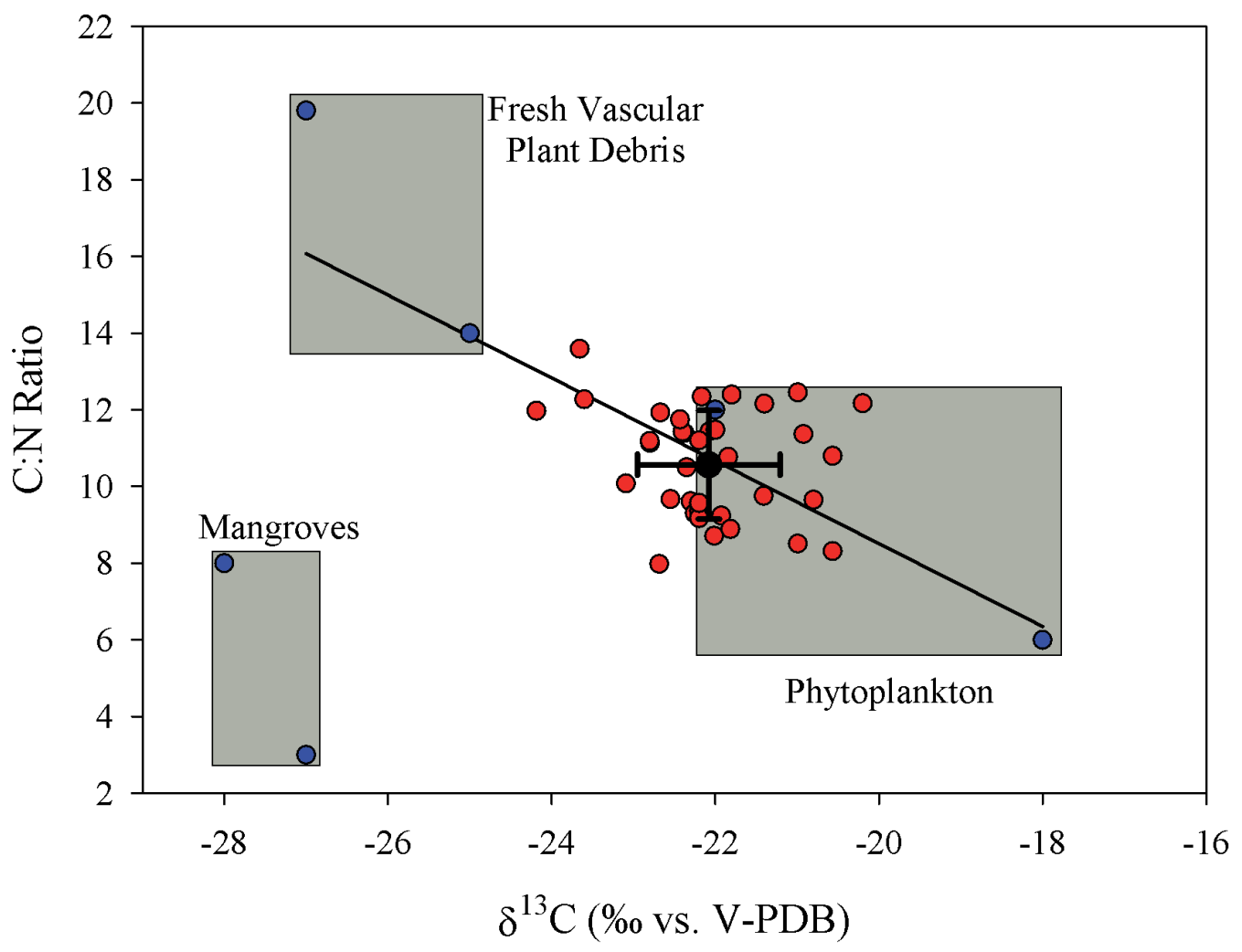

Fig. 3.- Scatter plots for the C:N ratio vs. the $\delta^{13} \mathrm{C}-\mathrm{TOC}$ (red circles) measured in surface sediments from southwestern Baja California Peninsula, Mexico. We have identified the range of compositions expected for the three most likely contributing sources of organic matter (end-members, gray boxes and blue circles): marine phytoplankton $\left(\mathrm{C}: \mathrm{N}\right.$ ratio $6-12 ; \delta^{13} \mathrm{C}:-18$ to $-22 \%$ ), mangroves $(\mathrm{C}: \mathrm{N}$ ratio $3-8 ; \delta^{13} \mathrm{C}:-27$ to $-28 \%$ ), and fresh vascular plant debris $\left(\mathrm{C}: \mathrm{N}\right.$ ratio $14-20 ; \delta^{13} \mathrm{C}:-25$ to $-27 \%$ ). Continuous lines have been drawn between the marine (phytoplankton) and terrestrial (fresh vascular plant debris) end-member compositions assumed for our study area. The green circles and bars indicate the mean and standard deviation of all data measured in surface sediments.

Fig. 3.- Diagrama de dispersión de la razón C:N vs $\delta^{13} \mathrm{C}$-COT (círculos rojos) medidos en sedimentos superficiales del suroccidente de la Península de Baja California, México. En la figura se identifica el intervalo de la composición esperada para las tres fuentes de materia orgánica (end-members, cajas grises y círculos azules): fitoplancton marino (razón C:N $6-12 ; \delta^{13} \mathrm{C}$ : -18 a $-22 \%$ ), manglar (razón C:N $3-8 ; \delta^{13} \mathrm{C}:-27$ a $-28 \%$ ), y plantas vasculares (razón C:N $14-20 ; \delta^{13} \mathrm{C}:-25$ to $-27 \%$ ). Las líneas continuas unen la composición de los end-member marino y terrestre supuestos para el área de estudio. Los círculos verdes y barras indican el promedio y desviación estándar de todos los datos medidos en sedimentos superficiales.

of the station 28 in the transect G (Fig. 2d; Table 1). The $\delta^{13} \mathrm{C}$ values are enriched in ${ }^{12} \mathrm{C}\left(\delta^{13} \mathrm{C}<-23 \%\right)$ in the shallow and coastal stations, except for stations 28 and 29 (Table 1).

\section{Discussion}

The distribution and sources of the OM has been extensively studied in transitional systems influenced by rivers and extreme runoffs (e.g., Hu et al., 2006; Niggemann et al., 2007; Cowie et al., 2009; Smith et al., 2008; Walinsky et al., 2009; Baumgart et al., 2010), which contrasts with the arid regions that are characterized by low terrigenous input and coastal upwelling, overlying an oxygen minimum zone. However, the contributions from the mangroves in the lagoon system of Bahia Magdalena-Almejas could be a significant source of OM to the margin of the southwestern Baja California Peninsula.

The C:N ratios and the $\delta^{13} \mathrm{C}$ values have been widely used as effective markers to estimate the relative proportions of terrigenous and marine organic matter in coastal and marginal sediments (Hu et al., 2006; Sánchez and Carriquiry, 2007a; Cowie et al., 2009; Walinsky et al., 2009; Aguiñiga et al., 2010; Baumgart et al., 2010). We have interpreted the spatial variations in the sediment $\mathrm{C}: \mathrm{N}$ ratio and $\delta^{13} \mathrm{C}$ in this context. It is generally accepted that terrestrial plants and marine algae have different $\mathrm{C}: \mathrm{N}$ ratios ( $\mathrm{N}$ taken as organic nitrogen) and $\delta^{13} \mathrm{C}$ values. The vascular terrestrial plants, rich in cellulose and lignin, have $\mathrm{C}: \mathrm{N}$ ratios $>15$ and $\delta^{13} \mathrm{C}$ values of $-34 \%$ to $-23 \%$, whereas marine protein-rich algae have lower $\mathrm{C}: \mathrm{N}$ ratios (6 to 12 ) and $\delta^{13} \mathrm{C}$ values of $-24 \%$ to $-18 \%$. The average $\mathrm{C}: \mathrm{N}$ ratio of $10.4 \pm 1.3$ 
$(\mathrm{n}=37)$ and carbon isotopic composition of $-20.6 \%$ to $-24.2 \%$ indicate a predominantly marine origin of deposited OM in the surface sediments (e.g., Sánchez and Carriquiry, 2007a; Cowie et al., 2009; Aguiñiga et al., 2010). However, the contribution of terrestrial organic matter is significant in the shallow and coastal stations in the study area.

By accepting uncertainties of using the $\mathrm{C}: \mathrm{N}$ ratio and carbon isotopic composition, the relative proportions of terrestrial and marine OM were assessed in sediments of the study area. The approach is based on the mixing model of Schultz and Calder (1976), which assumes $\delta^{13} \mathrm{C}$ values of various terrestrial and marine end-members. For the study area, the $\delta^{13} \mathrm{C}$ value of the terrestrial end-member was based on the $\delta^{13} \mathrm{C}$ value of mangroves $(-27 \%$ ). We have also assumed a value of $\delta^{13} \mathrm{C}$ of $-20.5 \%$ for the marine end-member for these calculations (e.g., Aguiñiga et al., 2010). Adopting the above end-member values, the relative percent of landderived $\mathrm{OM}$ in individual sediments of the study area was estimated after the Schultz and Calder (1976) equation.

The $\delta^{13} \mathrm{C}$ signatures for the surface sediment lie mostly within the range of marine organic material (from $-23 \%$ to $-20 \%$ from marine phytoplanktonic sources, Fig. 3). The most negative values recorded $\left(\delta^{13} \mathrm{C}=\right.$ $-24.2 \%$, $-23.7 \%$, and $-23.6 \%$ for the stations 1,9 , and 10) would show a contribution of about $57 \%, 49 \%$, and $48 \%$ of terrestrial carbon, assuming values of $-20.5 \%$ and $-27 \%$ for the marine and terrestrial end-members. The stations $22(33 \%)$ and $28(6 \%)$ showed less terrestrial contribution because of the mixing with phytoplankton sources (i.e., Martínez-López et al., 2004). The average value for $\delta^{13} \mathrm{C}$ surface sediments was $-22 \%$, indicating a $23 \%$ contribution from the scarce local desert vegetation or the mangroves.

Smith et al. (2008) suggested that the maximum terrigenous TOC content of sediments in Bahia Todos Santos is $<50 \%$ with an average near $30 \%$, where the $\mathrm{OM}$ contribution of terrigenous origin increases in the offshore direction. However, the sedimentation rate might alter the estimated average terrigenous contents, but these authors suggest that this effect would be relatively small. Further offshore, the TOC contents progressively decrease, presumably caused by a reduction in the marine production, although the $\mathrm{C}: \mathrm{N}$ ratio and $\delta^{13} \mathrm{C}$-TOC have a tendency towards a marine signal (e.g., Hu et al., 2006). There is a net increase seaward in $\mathrm{C}: \mathrm{N}$ ratio and depleted of $\delta^{13} \mathrm{C}$-TOC in sediments along the southwestern Baja California Peninsula. A straightforward explanation for this trend is a progressive sea- ward decrease in the proportions of terrigenous organic matter relative to marine organic matter (e.g., Cowie et al., 2009).

When examined as the $\mathrm{C}: \mathrm{N}$ ratio vs. the $\delta^{13} \mathrm{C}$-TOC (Fig. 3), the data suggest that the fresher forms of phytoplankton debris dominate over the terrestrial component along the southwestern Baja California Peninsula. In effect, Silverberg et al. (2004) obtained data that showed the $\mathrm{C}: \mathrm{N}$ ratio of the particulate organic matter (POM), collected from a sediment trap in the Soledad Basin, ranged from 8 to 12 . The higher value of the $\mathrm{C}: \mathrm{N}$ ratio is almost twice the Redfield ratio, but is still characteristic of marine-derived OM. This interpretation is supported by data from the $\delta^{13} \mathrm{C}-\mathrm{POM}$ that had a range of -20.5 to $-23 \%$, a typical planktonic OM (Goericke and Fry, 1994). The higher values of the $\mathrm{C}: \mathrm{N}$ ratio of the $\mathrm{POM}$ and OM may be indicative of the preferential use of nitrogen during the remineralization of the POM and OM of marine origin. Sanchez and Carriquiry (2007a) found that the $\mathrm{C}: \mathrm{N}$ ratio along the sedimentary record (GC31 and PC08 sediment core) had an average of 10 (maximum 13 and minimum 8) in the Magdalena margin. This suggests a source of OM dominantly of marine origin, mainly composed of diatoms (e.g., Sánchez and Carriquiry, 2007a,b; Carriquiry and Sánchez, 2010; Sánchez et al., 2010).

The presence of benthic diatom assemblages of the Bahia Magdalena-Almejas lagoon system in a sediment trap from the Soledad Basin has been suggested as the source of $\mathrm{OM}$ to be the adjacent continental margin (Martínez-López et al., 2004). The diatom assemblages were described as characteristic of the mangroves in Bahia Magdalena and the rocky coast. Moreover, the $\mathrm{C}: \mathrm{N}$ ratio of the mangroves is a low 3 to 4 in Avicenia germina sand Rhizopora mangle, with a maximum of 8 for Laguncularia recemosa, and a carbon isotopic composition of $-27 \%$ to $-28 \%$ o for the mangroves. The bacterial activity on the decomposition of mangrove leaves leads to a decrease in the $\mathrm{C}: \mathrm{N}$ ratio (e.g., Cifuentes et al., 1996; Gonneea et al., 2004). The $\mathrm{C}: \mathrm{N}$ ratio and the $\delta^{13} \mathrm{C}$-TOC at the coastal stations $(1,9,10,22$, and 28$)$ do not correspond with $\mathrm{C}: \mathrm{N}$ ratio derived from the mangrove environment. We recommend making studies to assess the OM contribution of the mangroves of Bahia Magdalena.

High OM contents have also been measured in the A, B, C, D, and E transects and the Soledad Basin (stations 31 and 26). However, primary productivity estimated from the chl- $\alpha$ from 1998 to 2005 (Martínez-Gaxiola et al., 2007) was higher in transects F, G, H, and I (Gulf of Ulloa and in front of the bays) than transects A, B, C, 
$\mathrm{D}$, and $\mathrm{E}$. This suggests that coastal upwelling has been more intense in the Gulf of Ulloa and in front of the lagoon system that in the region SE of the study area.

What controls the content of TOC? The presence or absence of oxygen is suggested to be a major factor for carbon burial (Hartnett et al., 1998). Hartnett et al. (1998) showed the importance of bottom oxygen waters for the TOC distribution in the northeastern Pacific (NEP) and concluded that primary production and oxygen concentrations play a crucial role in the distribution of OM in the sediments. Canfield (1994) suggested that the accumulation efficiency of the TOC decreases with increasing primary productivity and the "rain" of the TOC is caused by the mixing of the labile and refractory TOC.

Most marine sediments are inhabited by a diverse community of protozoans and metazoans varying in size from few tens of $\mu \mathrm{m}$ to a few $\mathrm{dm}$. These organisms have a number of direct and indirect effects on sediment biogeochemistry and OM processing (Meysman et al., 2006). Direct effects of animals on OM processing include organic consumption, transformation and production by animals, while indirect effects relate to modifying textures, biodeposition, bio-irrigation, bioturbation and grazing on bacteria. Burrowing organisms influence sediment properties such as porosity, permeability, and compaction, glue particles together into aggregates upon egestion and tube building and segregate particles during digestion. These processes alter OM-mineral-water interactions and thus the exposure of OM to hydrolytic enzymes and oxidants.

Berelson and Stott (2003) found that the burial efficiency of the TOC for the past 100 years was lower along the California coast and concluded that the efficiency of TOC accumulation was not related to the exposure time to oxygen. This would explain the low content of the TOC in the Gulf of Ulloa and in front of the lagoon system of Bahia Magdalena-Almejas, where the mixture of labile and refractory $\mathrm{OM}$ would limit the content of the TOC.

The oxygen minimum zone (OMZ, which characterizes the NEP) is broader in transects A, B, C, D, and $\mathrm{E}$ than in transects $\mathrm{F}, \mathrm{G}, \mathrm{H}$, and $\mathrm{I}$. The $\mathrm{OMZ}$ has a top and bottom border between 200-m and 800-m depth in transects A, B, C, D, and E. In transects F, G, H, and $\mathrm{I}$, the $\mathrm{OMZ}$ is narrower with a range of a $300-$ to 500 $\mathrm{m}$ depth. This produces a better preservation and accumulation of the TOC, though some studies found no statistical relation between the TOC burial and oxygen concentrations.

\subsection{Paleoceanographic implications}

Ocean margins are sites of high rates of OM production, with roughly half of oceanic primary production occurring along margins. Huge amounts of terrestrial $\mathrm{OM}$ are exported from the continent to the ocean margins, thereby directly linking the terrestrial and marine carbon cycles. The predominantly marine nature of the $\mathrm{OM}$ accumulating in these depositional environments indicates that most $(>50 \%)$ of the terrigenous $\mathrm{OM}$ is mineralized during its transport to, and within, the ocean (Walsh, 1991; Lui et al., 2000). Overall, the fate of terrigenous $\mathrm{OM}$ in the continent and in the ocean, as well as the nature and fraction of the terrestrial OM preserved in marine sediments, are poorly constrained (Hedges et al., 1997). These findings indicate the need to consider changes in $\mathrm{OM}$ composition in terrigenous carbon fluxes to marine settings. Paleoceanographic studies based on $\mathrm{C}: \mathrm{N}$ ratio and $\delta^{13} \mathrm{C}$-TOC on marine sediments could benefit in order to trace carbon from terrestrial plants, where a change in rainfall (multidecadal and millennial scale), could modify the abundance, composition and supply of terrestrial vegetation in continental margin sediments along the southwestern Baja California Peninsula. This study is the first sedimentary record about the relative contribution of the sources of organic matter in marine conditions of intense activity in this region. This will contrast the sources of organic matter in wetter conditions and low marine productivity in the past.

\section{Conclusions}

There have been a few studies of arid coastal systems with a low transport from the land, an active coastal upwelling, and an oxygen minimum zone in the context of their geochemical cycles. The spatial distributions of TOC, TN, the C:N ratio, and the $\delta^{13} \mathrm{C}$-TOC in sediments along the southwestern Baja California Peninsula are broadly similar. The low TOC contents, higher $\mathrm{C}: \mathrm{N}$ ratio, and depleted $\delta^{13} \mathrm{C}$-TOC values at the coastal stations and along the SW coast indicate higher terrestrial POM deposition and lower primary production. The $\mathrm{C}: \mathrm{N}$ ratio and the $\delta^{13} \mathrm{C}$-TOC values of sediments $(-24.2 \%$ o to $-20.2 \%$ ) indicate that the sedimentary organic matter is derived from both marine algae and terrestrial plants with little or no contribution from the mangroves. The estimates of algal-derived organic carbon based on a Two-End Member Mixing model shows that organic matter inputs from marine algae are low $(<40 \%)$ at the coastal stations. On the outer shelf and slope, the TOC 
contents are relatively high $(>70 \%)$, which may reflect enhanced marine production in the region, caused by an influx of TOC and OM accumulation in the oxygen minimum zone (transects A, B, C, D, and E).

\section{Acknowledgements}

This work was funded by projects SIP-IPN (20110143 and 20120689), awarded to Alberto Sánchez, CICIMAR-IPN, and project EP2 coordinated by Eduardo F. Balart, CIBNOR. We thank the crew of R/V BIP XII- CIBNOR for their support during the sampling at sea. We are also grateful to Dr. John Armstrong for constructive comments on an earlier version of our paper. Thanks are due to Dr. Ellis Glazier for editing this English-language text.

\section{References}

Aguíñiga, S., Sánchez, A., Silverberg, N. (2010): Temporal variations of $\mathrm{C}, \mathrm{N}, \delta^{13} \mathrm{C}$, and $\delta^{15} \mathrm{~N}$ in organic matter collected by a sediment trap at Cuenca Alfonso, Bahía de la Paz, SW Gulf of California. Continental Shelf Research 30, 1692-1700. doi: 10.1016/j.csr.2010.07.005.

Baumgart, A., Jennerjahn,T., Mohtadi, M., Hebbeln, D.(2010): Distribution and burial of organic carbon in sediments from the Indian Ocean upwelling region off Java and Sumatra, Indonesia. Deep-Sea Research I 57, 458-467. doi:10.1016/j.dsr.2009.12.002.

Berner, R.A. (1982): Burial of organic carbon and pyrite sulfur in the modern ocean: its geochemical and environmental significance. American Journal of Science 282, 451-473. doi: 10.2475/ajs.282.4.451.

Berelson, W., Stott, L.D. (2003): Productivity and Organic Carbon Rain to the California Margin Sea Floor: Modern and Paleoceanographic Perspectives. Paleoceanography 8, 1002. doi: 10.1029/2001PA000672.

Canfield, D.E. (1994): Factors influencing organic-carbon preservation in marine sediments. Chemical Geology 114, 315-329. doi: 10.1016/0009-2541(94)90061-2.

Carriquiry, J., Sanchez, A. (2010): Ópalo biogénico sedimentario en el extremo Sur del sistema de surgencias de la Corriente de California: etapas isotópicas marinas 1-5. In: G. Gaxiola, R. Durazo (eds.), Dinámica del Ecosistema Pelágico frente a Baja California: 19972007. INE, CICESE, México: 227-238.

Cifuentes, L. A., Coffin, R. B., Solorzano, L., Cardenas, W., Espinoza J., Twilley, R. R. (1996): Isotopic and elemental variations of carbon and nitrogen in a mangrove estuary. Estuarine, Coastal and Shelf Science 43, 781-800. doi: 10.1006/ecss.1996.0103.

Cowie, G.L., Mowbray, S., Lewis, M., Matheson, H., McKenzie, R. (2009): Carbon and nitrogen elemental and stable isotopic compositions of surficial sediments from the Indus margin of the Arabian Sea. Deep-Sea Research II 56, 271-282. doi: 10.1016/j.dsr2.2008.05.031.

Escobar-Briones, E., García-Villalobos, F.J. (2009): Distribution of total organic carbon and total nitrogen in deep-sea sediments from the southwestern Gulf of Mexico. Boletín de la Sociedad Geológica Mexicana 61, 73-86.

Goericke, R., Fry, B. (1994): Variations of marine plankton $\delta{ }^{13} \mathrm{C}$ with latitude, temperature and dissolved $\mathrm{CO}_{2}$ in the world ocean. Global Biogeochemical Cycles 8, 85- 90. doi: 10.1029/93GB03272.

Gonneea, M., Paytan, A., Herrera-Silveira, J. (2004): Tracing organic matter sources and carbon burial in mangrove sediments over the past 160 years. Estuarine, Coastal and Shelf Science 61, 211-227. doi: 10.1016/j.ecss.2004.04.015.

Hartnett, H.E., Keil, R.G., Hedges, J.I., Devol, A.H. (1998): Influence of oxygen exposure time on organic carbon preservation in continental margin sediments. Nature 391, 572-574. doi: 10.1038/35351.

Hedges, J.I., Keil, R.G., Benner, R. (1997): What happens to terrestrial organic matter in the ocean?. Organic Geochemistry 27, 195-212. doi: 10.1016/S0146-6380(97)00066-1.

Hu, J., Peng, P., Jia, G., Mai, B., Zhang, G. (2006): Distribution and sources of organic carbon, nitrogen and their isotopes in sediments of the subtropical Pearl River estuary and adjacent shelf, Southern China. Marine Chemistry 98, 274-285. doi: 10.1016/j.marchem.2005.03.008.

Limoges, A., Kielt, J.F., Radi, T., Ruiz-Fernandez, A.C., de Vernal, A. (2010): Dinoflagellate cyst distribution in surface sediments along the south-western Mexican coast (14.76-N to 24.75-N). Marine Micropaleontology 76: 104-123. doi: 10.1016/j.marmicro.2010.06.003.

Liu, K.K., Atkinson, L., Chen, C.T.A., Gao, S., Hall, J., Macdonald, R.W., Talaue McManus, L., Quiñones, R. (2000): Exploring continental margin carbon fluxes on a global scale. Eos, Transactions American Geophysical Union 81, 641-644. doi: 10.1029/EO081i052p00641-01.

Martínez-Gaxiola, M. D., Sosa-Ávalos, R., Gaxiola-Castro, G. (2007): Capítulo 17 Producción de carbono orgánico de los mares mexicanos (1998-2005). In: B. Hernández-De la Torre, G. Gaxiola-Castro (eds.), Carbono en Ecosistemas Acuáticos de México. INE, CICESE, México: 251-266.

Martínez-López, A., Siqueiros-Beltrones, D. A, Silverberg, N. (2004): Transporte de diatomeas bentónicas sobre la plataforma continental en frente de la parte sur de la península de Baja California. Ciencias Marinas 30, 503-513.

Meysman, F. J. R., Middelburg, J. J., Heip, C. H. R. (2006): Bioturbation: A fresh look at Darwin's last idea. Trends Ecology Evolution 21, 688-695. doi: 10.1016/j.tree. 2006.08.002.

Minoura, K., Hoshino, K., Nakamura, T., Wada, E. (1997): Late Pleistocene-Holocene paleoproductivity circulation in the Japan Sea: sealevel control on $\delta^{13} \mathrm{C}$ and $\delta^{15} \mathrm{~N}$ records of sediment organic material. Palaeogeography, Palaeoclimatology, Palaeoecology 135, 41-50. doi: 10.1016/S0031-0182(97)00026-6.

Muller-Karger, F. E., Varela, R., Thunell, R., Luerssen, R., Hu C., Walsh, J. J. (2005): The importance of continental margins in the global carbon cycle. Geophysical Research Letters 32, L01602. doi: 10.1029/2004GL021346.

Niggemann, J., Ferdelman, T.G., Lomstein, B.A., Kallmeyer, J., Schubert, C.J. (2007): How depositional conditions control input, composition, and degradation of organic matter in sediments from the Chilean coastal upwelling region. Geochimica et Cosmochimica Acta 71, 1513-1527. doi: 10.1016/j.gca.2006.12.012.

Sánchez, A., Carriquiry, J. (2007a): Accumulation of Corg, Norg, Porg and BSi off the Magdalena margin, BCS (Mexico), during the past 26 kyr. Ciencias Marinas 33, 23-35.

Sánchez, A., Carriquiry, J. (2007b): Capítulo 29 Flujos de carbono orgánico sedimentario a lo largo de la margen continental del Pacífico nororiental mexicano. In: B. Hernández-De la Torre, G. GaxiolaCastro, G. (eds.), Carbono en Ecosistemas Acuáticos de México. INE, CICESE, México: 427-436.

Sánchez, A, Carriquiry, J.D. (2011): Chapter 1 Sediment transport patterns in Todos Santos Bay, Baja California, Mexico, inferred from grain-size trends. In: A. Mannig (ed.), Sediment transport in Aquatic environments. Intech, Croacia: 1-18. doi: 10.5772/827.

Sánchez, A., Carriquiry, J., Barrera, J., López-Ortiz, B.E. (2009): Comparación de modelos de transporte de sedimento en la Bahía Todos Santos, Baja California, México. Boletín de la Sociedad Geológica Mexicana 61, 13-24.

Sánchez, A., Carriquiry, J., López-Ortiz, B.E. (2010): Variabilidad climática y la acumulación de carbono orgánico en el sector sur de la 
Corriente de California durante las etapas isotópicas marinas 1, 2 y 3 . Boletín de la Sociedad Geológica Mexicana 62, 391-398.

Schultz, D., Calder, J.A. (1976): Organic carbon ${ }^{13} \mathrm{C} /{ }^{12} \mathrm{C}$ variations in estuarine sediments. Geochimica et Cosmochimica Acta 40, 381-385. doi: 10.1016/0016-7037(76)90002-8.

Silverberg, N., Martinez, A., Aguíñiga, S., Carriquiry, J.D., Romero, N., Choumiline, E., Soledad Cota, S. (2004): Contrasts in sedimentation flux below the southern California Current between late 1996 and during the El Niño event of 1997-98. Estuarine, Coastal and Shelf Science 59, 575-587. doi: 10.1016/j.ecss.2003.11.003.

Smith, S.V., Ibarra-Obando, S. E., Diaz-Castañeda, V.M., ArandaManteca, F., Carriquiry, J.D., Popp, B.N., Gonzalez-Yajimovich, O. (2008): Sediment organic carbon in Todos Santos Bay, Baja California, Mexico. Estuaries and Coastal 31. doi: 10.1007/s12237-0089054-7.
Verma, S.P., Díaz-González, L. (2012): Application of the discordant outlier detection and separation system in the geosciences. International Geology Review. doi: 10.1080/00206814.2011.569402 (in press).

Verma, S.P., Quiroz-Ruiz, A., Díaz-González, L. (2008): Critical values for 33 discordancy test variants for outliers in normal samples up to sizes 1000, and applications in quality control in Earth Sciences. Revista Mexicana de Ciencias Geológicas 25, 82-96.

Walsh, J.J. (1991): Importance of continental margins in the marine biogeochemical cycling of carbon and nitrogen. Nature 350, 53-55. doi: 10.1038/350053a0.

Walinsky, S.E., Prahl, F.G., Mix, A.C., Finney, B.P., Jaeger, J.M., Rosen, G.P. (2009): Distribution and composition of organic matter in surface sediments of coastal Southeast Alaska. Continental Shelf Research 29, 1565-1579. doi: 10.1016/j.csr.2009.04.006. 